\title{
DOES THE IMPLEMENTATION OF LOYALTY PROGRAMMES LEAD TO GAINING A LOYAL CUSTOMER?
}

\section{${ }^{a}$ MICHAELA ŽILINSKÁ, 'bAROMÍR VRBKA, ${ }^{\mathrm{c} E V A}$ KALINOVÁ}

${ }^{a}$ Institute of Technology and Business in České Budějovice, School of Expertness and Valuation, Okružní 517/10 37001 České Budějovice, Czech Republic

${ }^{\mathrm{b}}$ Institute of Technology and Business in České Budějovice, School of Expertness and Valuation, Okružní 517/10 37001 České Budějovice, Czech Republic ${ }^{c}$ University of Žilina, The Faculty of Operation and Economics of Transport and Communication, Department of Economics, Univerzitna 8215/1, 01026 Žilina, Slovakia email: ${ }^{a}$ mzilinska@mail.vstecb.cz, ${ }^{b}$ vrbka@mail.vstecb.cz. ckalinova@mail.vstecb.cz

Abstract: An increasing number of retailers and service providers are aware of the importance of loyalty programmes as a tool to support sales. The aim of this paper is to evaluate the benefits of loyalty cards for sales support at three selected companies in the Czech market, especially Kaufland, Globus and Tesco, and to determine whether the implementation of the loyalty programme leads to gaining a loyal customer. The basic source of data is the data obtained through an interview and the CAWI method, which consists in collecting data using an online questionnaire survey. The obtained data are evaluated using a prognostic marketing and comparison method. In total, responses were obtained from 121 respondents. The results of the research show that the implementation of loyalty programmes does not lead to gaining a more loyal customer. If the customer does not have to register to join the programmer, he does not perceive himself as loyal to the brand. The Kaufland Card programme has become the most used loyalty programme. These conclusions lead to new ideas that could affect both the future development of loyalty programmes and their structure.

Keywords: customers, retail chains, benefits, loyalty, loyalty programme, loyalty cards

\section{Introduction}

Today, more and more companies are coming to the market and their competitive environment is constantly growing. A limited number of customers can be considered one of the most handled problems of these companies. For this reason, it is essential for companies to emphasize the satisfaction and care of each of their customers, because they are irreplaceable sources of income for companies. If customers are satisfied, then they tend to return and buy more goods than dissatisfied customers. Over time, satisfied customers become permanent customers. If the customer is satisfied, his or her purchases are repeated and thus ensure a stable turnover for the company due to the fact that they no longer need to look for discounts but are willing to buy the product from the company without being at a discount.

The current trend for retailers is loyalty cards as a form of sale. A strong motivation for handling this issue is the fact that thanks to a satisfied customer the company gains a better position in the market and thanks to this a precondition is created to ensure long-term existence (Zamazalová, 2008; Klieštik et al., 2020).

Loyalty programmes serve to strengthen relationships with customers, for example through direct discounts or special rewards (Bijmolt and Verhoef, 2017). Loyalty cards provide retailers with the means to help them identify a particular customer and to collect customer-specific data, enabling individualized marketing (Perez et al., 2020).

We live in a time when new communication technologies are developing at an incredible speed, especially easier communication between retailers and their customers. Due to the strong competitive environment, it is important that companies pay attention to the marketing tools that will serve to support their sales. Retaining a new customer is not easy and at the same time it is very expensive, so investing in these programmes pays off to the companies. With these programmes, they can attract new customers to their side in the long run.

The goal of this seminar thesis is to evaluate the benefits of loyalty cards for sales support at three selected companies in the Czech market, especially Kaufland, Globus and Tesco and to determine whether the implementation of the loyalty program leads to gaining a loyal customer. In order to meet the goal, the following research questions were formulated:

RQ1: What factor most influences the customer's shopping behaviour?

RQ 2: Does the implementation of the loyalty programme lead to gaining a loyal customer?

RQ3: Why do customers become members of loyalty programmes?

RQ4: What is the attitude of customers to loyalty programmes? RQ5: Which loyalty programme is the most used among customers?

\section{Literature review}

Zakaria, Rahman and Othman (2012) claim that the economic crisis after 2008 has significantly increased the entrance of new businesses into the consumer market, thus significantly increasing competition in this type of market. Therefore, a large part of retailers has introduced the so-called LP (loyalty programme), which serves mainly to maintain customer loyalty, and thus to prevent the customer's switching to a competitor. Loyalty programmes, such as the predominant CRM (Customer relationship management) strategies, are intended to strengthen customer loyalty and thus ensure the company's long-term profitability (Gandomi and Zolfaghari, 2013). These programmes are intended not only to help meet the company's goals, but also to serve as a valuable source of information that will help to communicate with customers better and also to build rewards (Tahal and Stř́iteský, 2014). Chaudhuri, Voorhees, and Beck (2019) examined the extent to which the introduction of LP can increase both fixed sales and gross profit. They took advantage of the fact that they had been provided 322 data from publicly traded companies and concluded that the introduction of LP can increase sales and gross profits in the short term (during the first year) and these positive effects are maintained in the long term (for at least three years).

However, one of the most discussed topics is customer loyalty. Noskova and Romanova (2015) found that the basic factor influencing customer loyalty is in the context of the 7P marketing mix (product, price, location, promotion, staff, physical evidence, and process) and states that the main factors influencing customer loyalty formation in retail chains are mainly rational (product, price, location, staff), regardless of the format of retailers. Omar et al. (2011) collected data from 400 loyalty programme cardholders and concluded that programme satisfaction is not related to trade loyalty, however, they argue that loyalty plays a crucial role in the relationship between programme satisfaction and trade loyalty.

Today's companies pay the most attention to acquiring new customers, so they lose interest in existing customers and neglect them, even though they generate up to $90 \%$ of their income. They spend up to $70 \%$ of marketing budgets on this, and as a result, retailers lose 10 to 30 percent of existing customers each year (Zamazalová, 2008). Many companies rely on LPs and are relatively successful in recruiting new members but are unable to attract them in the long run (Bruneau, Swaen, and Zidda, 2018). Customers refuse to accept a new loyalty card if they have difficulty understanding and learning how the loyalty card works and if they do not perceive it as easy to use (Demoulin and Zidda 2009). Paulssen, Brunneder and Sommerfeld (2019) were the first to empirically test customer behaviour in and out of the retail environment and advise managers intending to invest in customer incentives (providing constructive feedback on products or services) to invest in activities based on customer identity.

Today, most customers own several loyalty cards from competing retailers. Demoulin and Zidda (2008) examined the impact of loyalty card ownership on loyalty and concluded that loyalty programmes are effective only when customers value the 
rewards associated with them and confirm through analysis that when cardholders are satisfied with the rewards programme, they are more loyal and less sensitive to the price advantage of the competitors than dissatisfied cardholders. Users feel the need to stay in the loyalty system and collect points to earn rewards that may not be very interesting to them most of the time (Sönmeztürk, Ayav and Erten, 2020). Dorotic et al. (2014) who examined the impact of rewards on members' behaviour, also identify with this topic. They concluded that companies should not put pressure on using and expiring of points and let members choose when and how many points they want to use in order to improve their shopping behaviour.

Murugan, Prasad and Mageh (2014) examined LP using factor analysis and found that quality, added value, comfort and userfriendliness positively affect overall customer satisfaction with the loyalty programme.

To fulfil the goal and answer the research questions, the CAWI method (Computer Assisted Web Interviewing) will be chosen, and a comparative and prognostic marketing method will be used for data processing and evaluation.

\section{Data and methods}

\subsection{Data}

For research, we will collect individual data using the CAWI method. The CAWI method consists in collecting data using an online questionnaire survey. The questionnaire will be created using the Survio.com website and will contain 20 time-saving anonymous questions. We will choose this server mainly due to its low cost and clear processing of results. The questions will be aimed at a group of people from the age of 18 and will mainly concern the use of loyalty cards, shopping behaviour and customer preferences. The questions will be of the single and multiple-choice type (one or more options). For some questions, the answer will be directly determined, for others it will be necessary for the respondents to write their own answer. We will post the finished questionnaire on social networks using a web link, which, after clicking on it, will make the questionnaire available to the respondents. In the questionnaire, we will focus on three selected retail chains, namely Kaufland, Tesco and Globus. We will also conduct an interview with the company whose programme will be most used among customers. We will ask the company questions about the time required to create a loyalty programme. We will also try to find out what costs had to be, what benefits the company plans to enrich the loyalty programme with, whether sales and numbers of customers increased after the launch of the loyalty programme, what the company expected from the launch of the loyalty programme and what the customer reaction was.

\subsection{Methods}

Data will be obtained from at least 100 respondents. The obtained data will be downloaded. The next step will be to edit and delete irrelevant data. The adjusted data will be evaluated both qualitatively and quantitatively. The questionnaire will be evaluated using statistical methods. We will use frequencies, especially absolute (specific number) and relative (it expresses the representation of a specific value in the total and is expressed as a percentage). We will calculate relative frequencies by dividing the absolute frequency by the total number of values. We will evaluate the data using a comparative and marketing forecasting method. The comparison method will consist of comparing data sets and finding out how the files differ and how they resemble. Using the marketing forecasting method, we will try to track and estimate their future course from the provided data and find key factors that can affect this course. The resulting data will be published in both graphical and written form.

\section{Results}

There are 121 respondents for each question. The ratio of men to women is $60.3 \%$ to $39.7 \%$. As shown in Graph 1, the predominant group of respondents was aged 46-55, representing $39.7 \%$. Another big group of $27.3 \%$ is the group of people aged $19-25$ years. The last big group of $19.8 \%$ is the group aged $36-45$ years. On the other hand, the least represented group is the group aged $26-35$ years $=>9.1 \%$, then $56-65$ years in the representation of $3.3 \%$ and $15-18$ years $=>0.8 \%$. There was no representation in the other groups. Respondents are mostly employed, entrepreneurs or students, in the total representation of $86.8 \%$. The others are either unemployed or retired $13.2 \%$.

Graph 1: Age of respondents

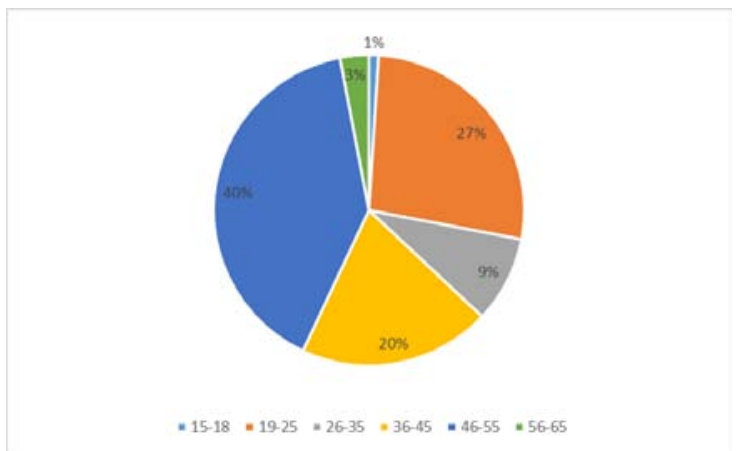

Source: Authors

Regarding the shopping behaviour shown in Graph 2, respondents most often make decisions based on the following factors: product price $69.4 \%$, product quality $46.3 \%$, product availability $40.5 \%$, location of branches and loyalty programme benefits $39.7 \%$, good experience with the shop $32.2 \%$, shop supply $28.1 \%$, brand $14.9 \%$ and staff behaviour $9.1 \%$. For this question, it should be noted that respondents had a choice of multiple answers. During one visit to the retail store, customers are willing to pay: CZK 500-1,000 $=>54.5 \%$, CZK $0-500=>$ $28.1 \%$, CZK 1,000-2,000 => 14\%, CZK 2,000-3,000 => 2.5\%, more than CZK 3,000 0.8\%.

Graph 2: Factors influencing customer decisions

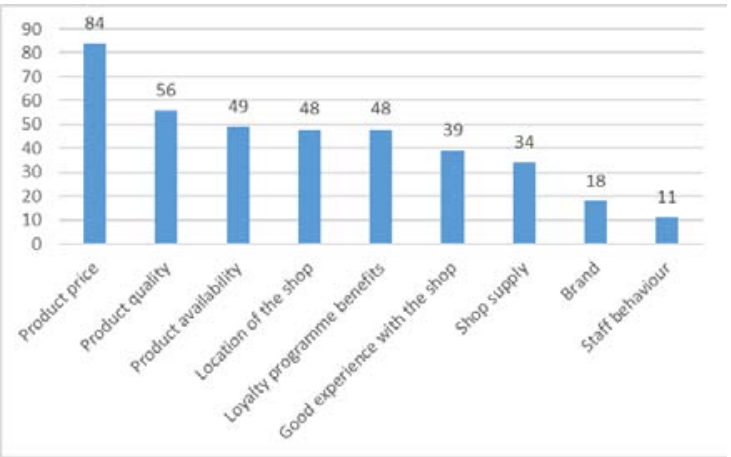

Source: Authors.

According to the evaluation, Kaufland becomes the most visited chain, with a total share of $57 \%$. Globus came in second with $38 \%$ and Tesco came in third with $25.6 \%$. 21.5\% of respondents visit other chains. Here again, it should be noted that it was a question of multiple choice. Only $18 \%$ of respondents are loyal to one chain, the remaining $82 \%$ are not loyal to any retail chain. $54.5 \%$ of respondents are members of the Kaufland Card loyalty programme, $45.5 \%$ are members of the Tesco Clubcard programme and $42.1 \%$ are members of the Globus Bonus programme. $14.9 \%$ are not members of any of the offered programmes. Again, it should be noted that this was a multiplechoice question. According to the respondents, the main reason for entering the loyalty programme was the possibility of 
obtaining discounts, for example in the form of a discount coupon, as well as the possibility of using scanners. Some respondents enter the programme automatically when they find out about it. Of the members of loyalty programmes, only $16.5 \%$ of respondents feel that they know most of the benefits. 59.5\% have a basic awareness and the remaining $24 \%$ do not know them at all. Respondents within the benefits of the loyalty programme most prefer the option of a discount coupon of $74.4 \%$, selected products with a discount of $67.8 \%$ and vouchers $43.8 \%$. On the contrary, the least preferred benefits are birthday benefits $13.2 \%$, competitions and information about news $5 \%$. $4.1 \%$ of respondents prefer other benefits, everything is shown in Graph 3. 36.4\% of respondents use the benefits of the loyalty programme weekly, $19.8 \%$ use them more often than once a month, 19.8\% (again) of respondents use the benefits once a month, $14.9 \%$ of respondents use the benefits several times a year and $9.1 \%$ of the respondents do not use any benefits.

Graph 3: Preference of benefits

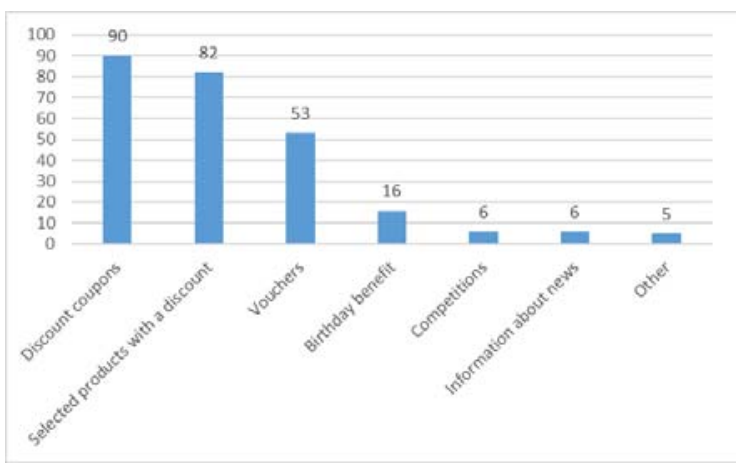

Source: Authors.

$10.5 \%$ of respondents started shopping more in the chain after entering the loyalty programme, or they spend more money there, $89.3 \%$ did not change their shopping behaviour. $1.7 \%$ of respondents started to be loyal to only one chain after establishing a loyalty card, the remaining $98.3 \%$ are not loyal, see Graph 4. Regarding the use of established loyalty cards, $41.3 \%$ use only a part of them, $35.5 \%$ use only one, $16.5 \%$ use all and $6.6 \%$ do not use any.

Graph 4: Respondents' loyalty to one chain after establishing a loyalty programme

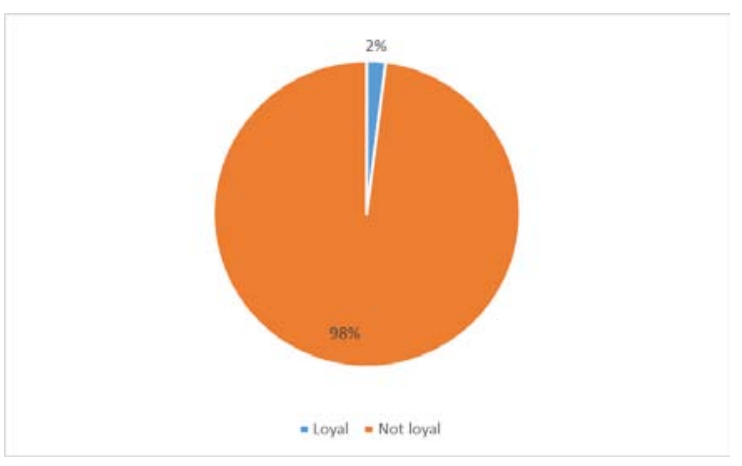

Source: Authors.

According to the respondents, the main disadvantages of loyalty programme membership include the provision of personal data, the loss of loyalty points, the lack of clarity of benefits, the constant questioning of saleswomen about a loyalty card and the excessive number of cards in the wallet. Respondents would enrich the loyalty programmes with the following benefits: scratch cards, $1+1$ product for free, cashback, setting up loyalty cards without the necessary registration, every 100th purchase with a $50 \%$ discount, sharing one account within one family and keeping receipts. According to the respondents, the most used loyalty programme is Kaufland Card with $45 \%$, Tesco Clubcard is in the second place with $18 \%$ and Globus Bonus is in the last place with $16 \%$. $21 \%$ of respondents are members of other loyalty programmes.

\section{Discussion}

Based on the obtained results, we can answer research questions that were set in the introduction. In total, answers were obtained from 121 respondents, which in comparison with the customer bases of these chains in the Czech Republic is really only an indicative sample. Using the first and last three questions, we mainly tried to profile the respondent and find out more about his purchasing decision-making process. We were interested in their gender, age, how often he or she visits the retail chains and what criteria are crucial for him or her when choosing a retail chain (the reason could have been the loyalty programme). Furthermore, what amount of money they spend on average during one visit to retail chain and to which group they belong (student, worker, pensioner, etc.). Questions 4 and 5 examined the attendance of three selected retail chains (Kaufland, Globus, Tesco), although it was possible to choose the option "none of the options offered" and customer loyalty to only one brand. Using the following twelve questions, we directly monitored the use and evaluation of selected loyalty programmes (Kaufland Card, Globus Bonus, Tesco Clubcard). The majority of openended questions can be found in this part of the questionnaire because we did not want to limit the respondents only to the options we selected, and we also wanted to give them the opportunity to express their opinion.

Due to the large representation of women, it can generally be said that the representatives of the fairer sex were much more communicative in open answers than men, so we were able to get much more information about them. The first research question focuses on which factor most influences the customer's shopping behaviour. At first glance, it is significant that financial factors play the largest role in decision-making. This is evidenced by the fact that respondents are willing to spend up to approximately CZK 1,000 on a single visit to a retailer. According to the evaluation, Kaufland is the most visited chain. Interestingly, however, only $18 \%$ of respondents are loyal to only one chain. Respondents who are not loyal, choose the chains because of current discount offers. Another reason is the preference of branches, which are closest to their current location and, last but not least, their decisions are influenced by the different assortment offer of chains. We were interested in what led the respondents to establish a loyalty programme, so we asked them an open question again. In addition, we got the answer to the second research question: Why do customers become members of loyalty programmes? It was not surprising that the main motivator was the possibility of saving money, especially through benefits such as discount coupons or discounts on selected products. On the contrary, the surprising and at the same time the most frequent answer of the respondents (33\%) was the possibility of using shopping scanners (scan \& go), with which the respondents will save time when shopping. We would like to point out that without membership in the loyalty programme, it is not possible to use scanners. However, the question remains whether the implementation of the loyalty programme helps to gain a loyal customer and the consequent greater profitability of companies. Here is the answer to the third research question: Does the implementation of the loyalty programme lead to gaining a loyal customer? The shocking result is that only $10.7 \%$ of respondents started buying more in a given chain, or spend more money there, and only $1.7 \%$ of respondents were influenced by the loyalty programme so much that after its establishment they became loyal to only one chain. As a result, the introduction of a loyalty programme does not lead to gaining a loyal customer.

The average Czech has 6 loyalty cards in his or her wallet, of which only 4 are used regularly. This is also evidenced by the fact that only $16.5 \%$ of respondents use all established loyalty cards. Here we would like to point out that most people enter the loyalty programme automatically when they learn about it. It is also important to mention the fact that for most users, the biggest 
problem is the need to carry a membership card with you at all times. If they do not have it, the relevant points will not be charged to them and thus they will lose possible benefits. Respondents who are not in any loyalty programme avoid them just because of the need to own loyalty cards. Fortunately, time goes on and larger retail chains connect users to their own accounts, where they see their points, have a better overview of the benefits available, such as what bonuses they can already reach, and receive regular information about current promotions.

Loyalty programmes have a lot of advantages, but also disadvantages. Another research question asked is: What is the attitude of customers to loyalty programmes? For this reason, we asked the respondents an open question, whether they perceive any disadvantages in connection with the loyalty program, or what benefits they would enrich the loyalty program. They perceive the provision of personal data, which are necessary for registration in the loyalty programme, as the predominant disadvantage. This condition makes them feel that they are being monitored and that their privacy will, or could be, unduly infringed. Another common disadvantage is the loss of unused loyalty points. By not having time to use all the points accumulated in time, customers lose the opportunity to obtain benefits such as discounts or vouchers. Customers are being pressured in this regard and therefore do not feel comfortable in the loyalty programme. Other disadvantages chosen by the respondents include constant questioning about the loyalty card by the saleswomen, lack of clarity of benefits or excessive ownership of the cards in the wallet. Regarding the enrichment of loyalty benefits, the respondents were very creative in this regard. The most interesting idea was to introduce scratch cards for a certain amount of purchase. In these scratch cards, after scratching them, for example, there would be a chance to get a discount on another purchase or a small promotional gift. Furthermore, respondents would welcome, for example, special events where there would be a $1+1$ product free, cashback, setting up a loyalty card without registration, every 100th purchase with a $50 \%$ discount, sharing one account within one family and keeping receipts.

The last and most important research question is: Which loyalty programme is the most used among customers? According to the respondents, the Kaufland Card programme became the most used loyalty programme. For this reason, we contacted Kaufland's headquarters and asked them a few key questions regarding the implementation and realization of the loyalty programme. The first question asked concerned the time required to create the programme. We received an answer that the implementation took approx. 10 months. However, this is only a figure within the Czech Republic. The overall creation of the project took more than two years and took place in Germany. In the next question, we asked how expensive the implementation of the K-card was. The cost of the programme is in the tens of millions of CZK, if we consider the development of IT infrastructure and the work of employees in Germany and the Czech Republic. However, the programme is being prepared for more countries, not only for the Czech Republic. Furthermore, what the company expected from the launch of the loyalty programme. The company expected that the customer would be more loyal, that they would be able to offer them a new benefit (the joy of shopping) and that they would be able to reward him for his loyalty in forms that would be "tailored" to him. However, the card is only a year after its creation, so they are still working on further development. We were interested in whether the number of customers and their sales increased after the launch of the loyalty programme on the market. The company replied that customer movements and market turnover are not given just by a loyalty card. They started with K-Card at a time when the Covid-19 crisis came, so separating, for example, these influences and others from customer numbers and turnover is difficult. But what the company knows is that their customer loyalty has increased. We also tried to find out whether the company plans to enrich the loyalty programme with other benefits in the future. Kaufland is planning several new card features. Customers already have the opportunity to get a discount on the entire purchase (buy it for points) - this is a more efficient way than sending vouchers by post. And the last question asked was what the reaction of customers to the Kaufland Card was. The customer response was very positive. Customers were very interested in registering the card and taking advantage of the discounts and benefits that the card offers. Customers also use the card to shop with a K-scan, which they cannot use without a loyalty program.

The results of the research clearly show the fact that the introduction of a loyalty programme does not lead to gaining a more loyal customer. The same statement is made by Omar et al. (2011), who also argue that satisfaction with the programme is not related loyalty to the shop. Customers enter loyalty programs only because of the possibility of obtaining financial benefits. In addition, as we have already mentioned, the main motivator for the establishment is also the possibility of using scan \& go shopping scanners, which customers cannot use without registering in the loyalty program. In addition, customers do not feel comfortable in loyalty programs due to pressure from retail chains and the need to provide personal information. A similar conclusion is reached by Dorotic et al. (2014), who believe that customers should not be pressured to apply loyalty points. Demoulin and Zidda (2008) argue that loyalty programs are effective only when customers value the rewards associated with them. However, I do not agree with this statement, in my opinion satisfaction with the programme and valuing the rewards is not related to loyalty to the program. In addition, most customers enter the loyalty programme immediately after the offer, without being attractive to them. For this reason, customers have 10 cards in their wallets and only use 4 of them. In our opinion, it is necessary to set the loyalty programme so that it is clear for everyone, advantageous, and also able to attract every age group.

These results can be a benefit to both retail chains thinking about implementing a loyalty programme and people who want to learn more about loyalty programs. In addition, someone can be inspired with these conclusions, or use them in other professional work

\section{Conclusion}

An increasing number of resellers and service providers are aware of the importance of loyalty programmes as a tool to support sales. But a simple implementation of these programmes is not enough. Its implementation must consider the costs of its implementation, the potential for building brand loyalty, integration with corporate strategy and truly beneficial benefits with added value for customers. In short, loyalty must really pay off for them.

The goal of the paper was to evaluate the benefits of loyalty cards for sales support and to find out whether the implementation of the loyalty programme leads to gaining a loyal customer. The goal was met. In the chapter of discussion, all research questions were answered. We evaluated and compared the results qualitatively and quantitatively. In the paper, we focused mainly on the use of loyalty cards and customer loyalty to retail chains. We received results that the introduction of a loyalty programme does not lead to gaining a more loyal customer. We have found that unless a customer needs to register to join the program, they do not perceive themselves as loyal to the brand. Retail loyalty programme developers should strive for simple systems that require registration that does not collect too much personal information.

The Kaufland Card programme has become the most used loyalty programme. For this reason, we conducted a short interview with the company, in order to find out more about the implementation and realization of this program.

The above results therefore lead to the following questions: Why the implementation of the loyalty programme does not help to gain a loyal customer? What needs to be done to prevent this from happening? What do customers expect from retail chains? For this reason, it is necessary to carry out follow-up research that will answer these questions and find a possible solution. 


\section{Literature:}

1. Bijmolt, T. H. A., Verhoef, P. C.: Loyalty programs: Current insights, research challenges, and emerging trends. In: Handbook of marketing decision models. Cham: Springer, 2017. 143-165 p. ISBN 978-3-319-56941-3.

2. Bruneau, V., Swaen, V., Zidda, P.: Are loyalty program members really engaged? Measuring customer engagement with loyalty programs. Journal of Business Research. 2018, 91, 144158 p. ISSN 0148-2963.

3. Demoulin, N. T. M., Zidda, P.: Drivers of customers’ adoption and adoption timing of a new loyalty card in the grocery retail market. Journal of Retailing. 2009, 85(3), 391-405 p. ISSN 0022-4359.

4. Demoulin, N. T. M., Zidda, P.: On the impact of loyalty cards on store loyalty: does the customers' satisfaction with the reward scheme matter? Journal of Retailing and Consumer Services. 2008, 15(5), 386-398 p. ISSN 0969-6989.

5. Dominiguez Peres, L. J., Ibarra, L., Alejandro, G. F.: A loyalty program based on Waves blockchain and mobile phone interactions. The Knowledge Engineering Review. 2020. ISSN 0269-8889.

6. Dorotic, M., Verhoef, P. C., Bijmolt, T. H. A.: Reward redemption effects in a loyalty program when customers choose how much and when to redeem. International Journal of Research in Marketing. 2014, 31(4), 339-355 p. ISSN 01678116.

7. Gandomi, A., Zolfaghari, S.: Profitability of loyalty reward programs: An analytical investigation. Omega. 2013, 41(4), 797807 p. ISSN 0305-0483.

8. Chaudhuri, M., Voorhees, C. M., Beck, J. M.: The effects of loyalty program introduction and design on short-and long-term sales and gross profits. Journal of the Academy of Marketing Science. 2019, 47(4) 640-658 p. ISSN 0092-0703.

9. Klieštik, T., Nica, E., Šuleř, P., Valášková, K.: Innovations in the company's earnings management: the case for the Czech Republic and Slovakia. Marketing And Management of Innovations. 2020, 3, 332-345 p. ISSN 2218-4511.

10. Murugan, A., Prasad, P. N., Mageh, R.: Factors affecting loyalty programmes and their influence on satisfaction of shoppers of organised retail stores. International Journal of Economic Research. 2014, 11(1), 127-138 p. ISSN 0972-9380.

11. Noskova, E. V., Romanova, I. M.: Evaluation of customer loyalty to different format retailers. The Journal of Internet Banking and Commerce, 2015. ISSN 1204-5357.

12. Omar, N. A., Aziz, N. A., Nazri, M. A.: Understanding the relationships of program satisfaction, program loyalty and store loyalty among cardholders of loyalty programs. Asian Academy of Management Journal. 2011, 16(1), 21-41 p. ISSN 1985-8280. 13. Paulssen, M., Brunneder, J., Sommerfeld, A.: Customer inrole and extra-role behaviours in a retail setting: the differential roles of customer-company identification and overall satisfaction. European Journal of Marketing. 2019, 53(12), 2501-2529 p. ISSN 0309-0566.

14. Sönmeztürk, O., Ayav, T., Erten, Y. M.: Loyalty program using blockchain. 3rd IEEE International Conference on Blockchain. 2020, 509-516 p.

15. Tahal, R., Stříteský, V.: Věrnostní programy a jejich vnímání zákazníky a provozovateli retailových internetových obchodů [Loyalty programs and their perception by customers and operators of retail online stores]. Acta Oeconomica Pragensia. 2014, 22(4), 30-41 p. ISSN 1804-2112.

16. Zakaria, I., Rahman, B. A., Othman, A. K.: The relationship between loyalty program and customer loyalty in retail industry: a case study. 2012 International Conference on Innovation Management and Technology Research. 2012, 33-38 p.

17. Zamazalová, M.: Spokojenost zákazníka [Customer satisfaction]. Acta Oeconomica Pragensia. 2008, 16(4) 76-82 p. ISSN 1804-2112.

Primary Paper Section: A

Secondary Paper Section: AH, AO 